\title{
Examining the Eating Habits of Children with Autism Spectrum Disorder and Typical Development with Regards to Certain Demographic Variables
}

\author{
Nur Sena ÖZ ${ }^{*}$, Pinar BAYHAN ${ }^{2}$, \\ ${ }^{1}$ M. Sc., Ankara University Faculty of Health Sciences Department of Child Development \\ ${ }^{2}$ Professor, Hacettepe University Faculty of Health Sciences Department of Child Development
}

\begin{abstract}
Eating problems may emerge during early childhood. If the eating problem is not physiological-oriented, child's relationship with its primary environment may be effective in this problem. For this reason, the aim of this study was to examine the eating habits of children with autism spectrum disorder (ASD) and typical development (TD) with regards to the variables like child's age, parental age, and presence of siblings.

Parents of a total of 180 children (90 with ASD and 90 with TD), who are enrolled in preschools, special education centers, and rehabilitation centers in Ankara-TURKEY, participated in the study. The Brief Assessment of Mealtime Behavior in Children (BAMBIC) and The Children's Eating Behavior Questionnaire (CEBQ) were used to identify children's eating habits. In addition, a personal information form was used to gather demographic information of the participants. The data obtained from 180 parents were analyzed with the help of relevant statistical programs.

According to the results, children with ASD have more food refusal and disruptive behavior at mealtime at the age of 3. The children with ASD and with TD of mothers aged 20-29 years have more food refusal at mealtime. On the other hand, those who have at least one sibling among the ones with ASD show more enjoyment of food and food responsiveness than typically developing ones with no sibling.
\end{abstract}

Keywords: autism spectrum disorder, eating habits, eating problems, mealtime. 


\section{Introduction}

Nutrition is a source of life and critical in every stages of human life. Even a newborn baby gets hungry and cries after a few hours from birth. Since there are individual differences in growth and development, eating habits may also vary between individuals (MEB, 2013, Yavuzer, 2016). Nutrition is the most critical step for the child to manage itself because it is important for the child to achieve autonomy and succeed in something on its own when it starts eating alone (Yavuzer, 2016). Children's understanding in concepts related to food, nutrition and healthy nutrition expands as the age advances (Xu \& Jones, 2016).

\subsection{Eating Behaviors and Characteristics in Early Childhood (3-6 Years)}

Children aged 3-6 may appear to eat less because they grow at a slower rate compared to the infancy (Baysal \& Arslan, 2007; Bee \& Boyd, 2009; Sümbül, 2009; Berk, 2015). Indeed, nutrition pattern in early childhood is not different from the parental eating habits. Eating habit of the family may shape the child's eating habit. Therefore, giving the child an opportunity to try different foods and getting it to be accustomed to varied foods might be an important step for the child to create its own eating habit (Köksal \& Gökmen, 2016). Eating behaviors directly affect physical, emotional-social and motor development of the child (Kaya, 1999). In addition, advances in these spheres of development affect nutrition. A child aged 3-6 years has mastered using spoon, fork and even knife, and is also able to wash and dry its hands (Yavuzer, 2013). It is able to determine the amount of its own food, put foods on its own plate, eat it without the need for adult support, and even clear its plate following the mealtime (Uyaroğlu, 2016).

\subsection{Eating Behaviors and Characteristics of Children with Autism Spectrum Disorder}

It is important to acquire an eating behavior for a child with typical development and its family as it is for a child with autism spectrum disorder and its family (Meral, 2017). A healthy behavior is important especially for children with autism spectrum disorder to reduce the symptoms of autism spectrum disorder, to improve expected behaviors, to eliminate the symptoms of concomitant diseases, and to improve the quality of life of children and their families (Uçar \& Samur, 2017). Since autism spectrum disorder is thought to be characterized by weak social interactions, limited interests and behaviors, they can be expected to exhibit limited dietary diversity behaviors during mealtimes (Meral, 2015; Balıkçı \& Çiyiltepe, 2017). Nutritional and metabolic status of children with autism spectrum disorders may differ compared to the ones with typical development (Ünal \& Özenoğlu, 2016). Sensory integration problems are more prevalent in children with autism spectrum disorder, which may reflect in children's eating behaviors. Sensory sensitivity behaviors such as sniffing food and consuming food according to their colors may be observed in such children (Bilbay, 2015). Children with autism spectrum disorder may have emotional perception disorders and experience eating problems due to hypersensitivity to the taste of foods (Bilbay, 2015). Eating behaviors of children with autism spectrum disorder can be listed as: not eating properly, eating fast, consuming inadequate food, keeping food in their mouths without swallowing. The most common one is selective eating (Balıkçı \& Çiyiltepe, 2017; Meral, 2017). It is thought that parents are worried inasmuch as they do not know how to approach their children in some cases. As an example, Sharp, Burrel, and Jaquess (2013) concluded in their study that the stress level of caregivers is reduced since the awareness of the caregivers about their 


\section{SOCIAL SCIENCES IN THE 21ST CENTURY}

attitudes towards their children at mealtimes is raised upon a training session related to mealtime plan for children with autism (Sharp, Burrel \& Jaquess, 2013).

\section{Methods}

The study was conducted based on survey design (Karasar, 2009; Erdoğan, Nahcivan \& Esin, 2014).

\subsection{Sampling procedures and the sample}

To determine the eating behaviors of children and parental attitudes during mealtime, the sample of the study was composed of children aged 3-5 years with TD and ASD, as well as their parents. The participants were chosen using the simple random sampling method. The children in the sample attended private pre-schools and private education and rehabilitation centers during the 2017-2018 academic year in eight different districts of Ankara, Turkey.

Firstly, the context of the study was discussed with 115 randomly selected private educationrehabilitation centers and 41 randomly selected private pre-schools. The research was carried out in 39 private education-rehabilitation centers and 18 private pre-schools, which agreed to participate in the study. The steps followed in sample size calculation are: type 1 error margin $(\alpha)=0.05$, effect size $=0.5$, testing power $=0.85$. Such calculations, at intended confidence level, revealed the total sample size as 180. Each parent was allowed to participate in the study with their only one child. Voluntary participation was essential for the study so that each parent who had agreed to participate in the study completed a consent form. The total sample was 180, in which 90 were parents of the children with TD and 90 were parents of children with autism spectrum disorders.

Figure 1. Distribution of sample by age group and gender

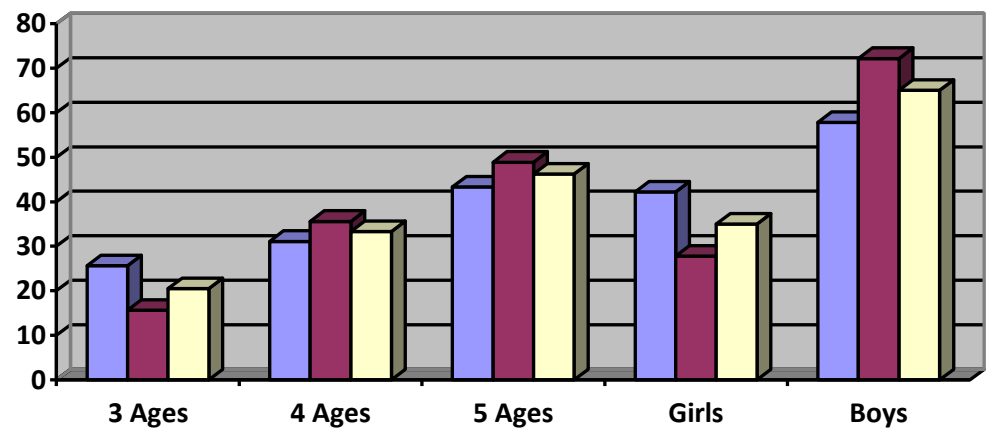

\subsection{Measures}

The "Brief Assessment of Mealtime Behavior in Children (BAMBIC)" and the "Children's Eating Behavior Questionnaire (CEBQ)" were used to determine the eating behaviors of the children, and the "Personal Information Form" was used to gather demographic information. 


\subsubsection{The Brief Assessment of Mealtime Behavior in Children (BAMBIC)}

The BAMBIC was developed by Hendy, Seiverling and Williams (2013) for the use in clinics and schools or at home by parents. It is a tool designed to provide an evaluation of the eating behaviors of children as a pre-assessment and consists of a questionnaire form including 10 items for parents. It is composed of 3 distinct sub-scales: limited variety, food refusal and disruptive behavior. The scale was administered to 139 children aged 18-212 months before. The scale gives different score values for 3 groups, which are the group with ASD, the group with TD and the group with those specific needs (Hendy et al., 2013; Seiverling et al., 2014).

In Turkey, the researchers adapted the scale in 2019. For the face validity, translation and back translation studies were carried out by two certified translators, then the quality of translations was checked by an expert in the field of Turkish Philology. For the content validity, the translated scale was submitted to nine experts for obtaining expert view. The content validity index (CVI) was determined as 0.75 . The final draft obtained following this process was administered a mother, who does not have an academic title, to test its intelligibility. For the construct validity, Confirmatory Factor Analysis (CFA) was applied to the final draft. Accordingly, it was observed that the value $\mathrm{x}^{2} / \mathrm{sd}(1,91)$ was under 5; the values of GFI (0.93), NFI (0.92) and CFI (0.96) were above 0.90; and the values of RMSEA (0.078) and SRMR (0.039) were under 0.08. Limited variety, food refusal and disruptive behavior were validated as the sub-scales of the BAMBIC. Factor loads $(\lambda)$ of the threedimensional model of the BAMBIC varied between 0.40-0.92 according to the standard solutions of error variance. It was obtained that the items were at intended level $(\geq 0,30)$ of factor load values (Brown, 2015). Accordingly, the model showed a good fit to the data in respect of both factors load values and the validity index. Finally, Cronbach- $\alpha$ coefficients were sought for the reliability analyses. Cronbach- $\alpha$ coefficients of the sub-scales showed a variance in the range of 0.68-0.92 (Öz \& Bayhan, 2019).

\subsubsection{The Children's Eating Behavior Questionnaire (CEBQ)}

The scale, which aims to determine eating behaviors of children, was developed by Wardle, Guthrie, Sanderson, Rapoport (2001). The original form of the scale consists of 35 items to which parents are supposed to respond. It is a 5-point Likert scale and contains 8 distinct subscales that are food responsiveness (FR), emotional over-eating (EOE), enjoyment of food (EF), desire to drink (DD), satiety responsiveness (SR), slowness in eating (SE), emotional under-eating (EUE), and food fussiness (FF) (Wardle et al., 2001).

The scale was adapted to Turkish by Y1lmaz, Esmeray and Erkorkmaz (2001). Cronbach- $\alpha$ coefficients of the sub-scales were in the range of 0.61-0.84 (Y1lmaz et al., 2011).

\subsubsection{Personal Information Form}

Personal Information Form seeks to find out the children's ages, parental age, children's gender, and the number of siblings. The questionnaire contains an informed consent form that introduces the researcher, explains the purpose of data collection, discloses that the collected data will be kept confidential, and indicates that the participation in this study should be totally voluntary. 


\section{SOCIAL SCIENCES IN THE 21ST CENTURY}

\subsection{Ethical Issue and Data Collection Procedures}

Relevant permissions to use the scales described above were obtained from the responsible authors. Before the administration process, an ethical approval was obtained from Hacettepe University Research Ethics Committee to be able to use the scales in the sample group. Practitioners ensured parents completed the consent forms and administered the BAMBIC and CEBQ to the volunteer parents at an available time for the schools and centers based on a predetermined practice plan. The administration process commenced for 4 months.

\subsection{Data analysis}

Kurtosis and skewness values of the scores were sought to determine whether the scores in the sub-scales distributed normally or not. In this regard, it is assumed that if the kurtosis and skewness values of the scores are between -1 and +1 , it can be asserted that there is a normal distribution in the data; otherwise it cannot. Moreover, it was examined whether the scores in the sub-scales showed statistically significant differences by predetermined categories of independent variables. Therefore, if the distribution of the scores in the sub-scales were normal in each category of the independent variable considered, independent samples t-test was used; if the number of categories was two, ANOVA was used. When the distribution of the scores of the sub-scales was considered normal in each category of the independent variables and the number of categories was two, Mann Whitney $U$ test was used for independent samples; and if the number of categories was more than two, Kruskal Wallis test was used.

\section{Results}

Table 1. Comparison of the differences between scores in the sub-scales of the BAMBIC and CEBQ by the children with TD and ASD

\begin{tabular}{|c|c|c|c|c|c|c|c|}
\hline & T Test & Groups & $\mathbf{N}$ & Mean sq. & Sd & $\mathbf{t}$ & $\mathbf{p}$ \\
\hline \multirow[t]{2}{*}{ BAMBIC } & \multirow[t]{2}{*}{ Limited variety } & $\mathrm{TD}$ & 90 & 10,23 & \multirow[t]{2}{*}{178} & \multirow[t]{2}{*}{$-1,09$} & \multirow[t]{2}{*}{0,28} \\
\hline & & ASD & 90 & 10,81 & & & \\
\hline \multirow{12}{*}{ CEBQ } & \multirow[t]{2}{*}{ Enjoyment of food } & TD & 90 & 16,02 & \multirow[t]{2}{*}{178} & \multirow[t]{2}{*}{$-0,81$} & \multirow[t]{2}{*}{0,42} \\
\hline & & ASD & 90 & 16,66 & & & \\
\hline & \multirow[t]{2}{*}{ Desire to drink } & TD & 90 & 7,88 & \multirow[t]{2}{*}{178} & \multirow[t]{2}{*}{$-0,88$} & \multirow[t]{2}{*}{0,28} \\
\hline & & ASD & 90 & 8,34 & & & \\
\hline & \multirow[t]{2}{*}{ Satiety responsiveness } & TD & 90 & 20,68 & \multirow[t]{2}{*}{178} & \multirow[t]{2}{*}{1,89} & \multirow[t]{2}{*}{0,06} \\
\hline & & ASD & 90 & 19,10 & & & \\
\hline & \multirow[t]{2}{*}{ Slowness in eating } & $\mathrm{TD}$ & 90 & 9,80 & \multirow[t]{2}{*}{178} & \multirow[t]{2}{*}{$-0,24$} & \multirow[t]{2}{*}{0,81} \\
\hline & & ASD & 90 & 9,93 & & & \\
\hline & \multirow[t]{2}{*}{ Emotional under-eating } & $\mathrm{TD}$ & 90 & 11,50 & \multirow[t]{2}{*}{178} & \multirow[t]{2}{*}{2,21} & \multirow[t]{2}{*}{0,03} \\
\hline & & ASD & 90 & 10,32 & & & \\
\hline & \multirow[t]{2}{*}{ Food fussiness } & TD & 90 & 8,41 & \multirow[t]{2}{*}{178} & \multirow[t]{2}{*}{0,68} & \multirow[t]{2}{*}{0,50} \\
\hline & & ASD & 90 & 8,07 & & & \\
\hline & Mann Whitney U Test & Groups & $\mathbf{N}$ & Mean rank. & Sum rank & $\mathbf{U}$ & $\mathbf{P}$ \\
\hline \multirow{4}{*}{ BAMBIC } & \multirow[t]{2}{*}{ Food refusal } & TD & 90 & 80,43 & 7239,00 & \multirow[t]{2}{*}{3144,000} & $0,01 *$ \\
\hline & & ASD & 90 & 100,57 & 9051,00 & & \\
\hline & Disruptive behavior & $\mathrm{TD}$ & 90 & 88,61 & 7974,50 & 3879,500 & 0,52 \\
\hline & & ASD & 90 & 92,39 & 8315,50 & & \\
\hline & Food responsiveness & $\mathrm{TD}$ & 90 & 89,25 & 8032,50 & 3937,500 & 0,75 \\
\hline CEBQ & & ASD & 90 & 91,75 & 8257,50 & & \\
\hline & Emotional over-eating & TD & 90 & 91,99 & 8279,00 & 3916,000 & 0,69 \\
\hline & & ASD & 90 & 89,01 & 8011,00 & & \\
\hline
\end{tabular}

The results of ANOVA and Kruskal-Wallis tests applied to the scores obtained from the subscales of the BAMBIC and CEBQ revealed that the scores of the children with TD in the subscales of the BAMBIC and CEBQ did not differ statistically by their ages ( $p>0.05$ ). 


\section{SOCIAL SCIENCES IN THE 21ST CENTURY}

Table 2. Comparison of the differences between the scores in the sub-scales the BAMBIC and CEBQ by the ages of children with ASD

\begin{tabular}{|c|c|c|c|c|c|c|c|c|}
\hline & ANOVA & Variance & Sum Sq. & Mean sq. & sd & $\mathbf{F}$ & $\mathbf{p}$ & Difference \\
\hline \multirow{3}{*}{ 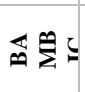 } & \multirow[t]{3}{*}{ Limited variety } & Between groups & 61,33 & 30,66 & 2 & \multirow[t]{3}{*}{2,14} & \multirow[t]{3}{*}{0,12} & \\
\hline & & Within groups & 1246,46 & 14,33 & 87 & & & \\
\hline & & Total & 1307,79 & & 89 & & & \\
\hline \multirow{13}{*}{ 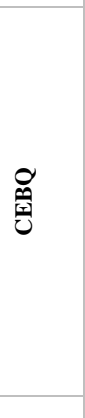 } & \multirow[t]{3}{*}{ Enjoyment of food } & Between groups & 22,40 & 11,20 & 2 & \multirow[t]{3}{*}{0,38} & \multirow[t]{3}{*}{0,68} & \\
\hline & & Within groups & 2545,92 & 29,26 & 87 & & & \\
\hline & & Total & 2568,32 & & 89 & & & \\
\hline & \multirow[t]{3}{*}{ Slowness in eating } & Between groups & 26,03 & 13,02 & 2 & \multirow[t]{3}{*}{0,96} & \multirow[t]{3}{*}{0,39} & \\
\hline & & Within groups & 1173,57 & 13,49 & 87 & & & \\
\hline & & Total & 1199,60 & & 89 & & & \\
\hline & \multirow[t]{3}{*}{ Emotional under-eating } & Between groups & 79,71 & 39,85 & 2 & \multirow[t]{3}{*}{3,12} & \multirow[t]{3}{*}{0,05} & \\
\hline & & Within groups & 1109,95 & 12,76 & 87 & & & \\
\hline & & Total & 1189,66 & & 89 & & & \\
\hline & \multirow[t]{3}{*}{ Food fussiness } & Between groups & 12,48 & 6,24 & 2 & \multirow[t]{3}{*}{0,51} & \multirow[t]{3}{*}{0,60} & \\
\hline & & Within groups & 1071,12 & 12,31 & 87 & & & \\
\hline & & Total & 1083,60 & & 89 & & & \\
\hline & Kruskal-Wallis & Group & $\mathbf{N}$ & Mean rank & sd & Chi-sqr. & p & Difference \\
\hline \multirow{6}{*}{ 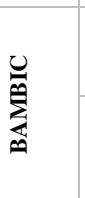 } & \multirow[t]{3}{*}{ Food refusal } & 3 Years & 14 & 62,07 & \multirow[t]{3}{*}{2} & \multirow[t]{3}{*}{7,14} & \multirow[t]{3}{*}{$0,03 *$} & \multirow[t]{3}{*}{$3>4$} \\
\hline & & 4 years & 32 & 40,77 & & & & \\
\hline & & 5 Years & 44 & 43,67 & & & & \\
\hline & \multirow[t]{3}{*}{ Disruptive behavior } & 3 Years & 14 & 59,11 & \multirow[t]{3}{*}{2} & \multirow[t]{3}{*}{9,08} & \multirow[t]{3}{*}{$0,01^{*}$} & $3>4$ \\
\hline & & 4 years & 32 & 39,80 & & & & \\
\hline & & 5 Years & 44 & 45,32 & & & & \\
\hline & Food responsiveness & 3 Years & 14 & 39,54 & 2 & 0,99 & 0,61 & \\
\hline & & 4 years & 32 & 47,78 & & & & \\
\hline & & 5 Years & 44 & 45,74 & & & & \\
\hline & Emotional over-eating & 3 Years & 14 & 42,11 & 2 & 0,30 & 0,86 & \\
\hline & & 4 years & 32 & 46,05 & & & & \\
\hline 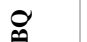 & & 5 Years & 44 & 46,18 & & & & \\
\hline 预 & Desire to drink & 3 Years & 14 & 40,86 & 2 & 1,37 & 1,37 & \\
\hline & & 4 years & 32 & 43,14 & & & & \\
\hline & & 5 Years & 44 & 48,69 & & & & \\
\hline & Satiety responsiveness & 3 Years & 14 & 52,29 & 2 & 1,14 & 0,57 & \\
\hline & & 4 years & 32 & 43,88 & & & & \\
\hline & & 5 Years & 44 & 44,52 & & & & \\
\hline
\end{tabular}

Table 3. Comparison of the differences between the scores of children with TD in the sub-scales of the BAMBIC and CEBQ by the ages of their mothers

\begin{tabular}{|c|c|c|c|c|c|c|c|c|}
\hline & ANOVA & Variance & Sum Sq. & Mean sq. & sd & $\mathbf{F}$ & $\mathbf{p}$ & Difference \\
\hline \multirow{6}{*}{ 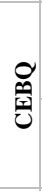 } & \multirow{3}{*}{ Food responsiveness } & Between groups & 51,41 & 25,71 & 2 & \multirow[t]{3}{*}{1,44} & \multirow[t]{3}{*}{0,24} & \\
\hline & & Within groups & 1549,57 & 17,81 & 87 & & & \\
\hline & & Total & 1600,99 & & 89 & & & \\
\hline & \multirow[t]{3}{*}{ Desire to drink } & Between groups & 65,93 & 32,96 & 2 & \multirow[t]{3}{*}{2,82} & \multirow[t]{3}{*}{0,07} & \\
\hline & & Within groups & 1017,73 & 11,70 & 87 & & & \\
\hline & & Total & 1083,66 & & 89 & & & \\
\hline & Kruskal-Wallis & Group & $\mathbf{N}$ & $\begin{array}{l}\text { Mean } \\
\text { rank }\end{array}$ & sd & $\begin{array}{l}\text { Chi- } \\
\text { sqr. }\end{array}$ & $\mathbf{p}$ & Difference \\
\hline \multirow{9}{*}{ 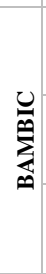 } & \multirow[t]{3}{*}{ Food refusal } & 20-29 Years & 21 & 50,19 & \multirow[t]{3}{*}{2} & \multirow[t]{3}{*}{6,23} & \multirow[t]{3}{*}{$0,04 *$} & \multirow[t]{3}{*}{$20-29>40$ years and older } \\
\hline & & 30-39 Years & 60 & 46,78 & & & & \\
\hline & & 40 years and older & 9 & 26,00 & & & & \\
\hline & \multirow[t]{3}{*}{ Limited variety } & 20-29 Years & 21 & 41,98 & \multirow[t]{3}{*}{2} & \multirow[t]{3}{*}{0,59} & \multirow[t]{3}{*}{0,74} & \\
\hline & & 30-39 Years & 60 & 46,93 & & & & \\
\hline & & 40 years and older & 9 & 44,17 & & & & \\
\hline & \multirow[t]{3}{*}{ Disruptive behavior } & 20-29 Years & 21 & 49,62 & \multirow[t]{3}{*}{2} & \multirow[t]{3}{*}{1,94} & \multirow[t]{3}{*}{0,38} & \\
\hline & & 30-39 Years & 60 & 45,03 & & & & \\
\hline & & 40 years and older & 9 & 39,00 & & & & \\
\hline \multirow{11}{*}{$\begin{array}{l}\text { O } \\
\text { 空 } \\
\text { Uै }\end{array}$} & \multirow[t]{3}{*}{ Emotional over-eating } & 20-29 Years & 21 & 42,36 & \multirow[t]{3}{*}{2} & \multirow[t]{3}{*}{0,46} & \multirow[t]{3}{*}{0,79} & \\
\hline & & 30-39 Years & 60 & 46,19 & & & & \\
\hline & & 40 years and older & 9 & 48,22 & & & & \\
\hline & \multirow[t]{3}{*}{ Enjoyment of food } & 20-29 Years & 21 & 45,07 & \multirow[t]{3}{*}{2} & \multirow[t]{3}{*}{3,40} & \multirow[t]{3}{*}{0,18} & \\
\hline & & 30-39 Years & 60 & 43,39 & & & & \\
\hline & & 40 years and older & 9 & 60,56 & & & & \\
\hline & \multirow[t]{3}{*}{ Satiety responsiveness } & 20-29 Years & 21 & 44,21 & 2 & 2,16 & 0,34 & \\
\hline & & 30-39 Years & 60 & 44,13 & & & & \\
\hline & & 40 years and older & 9 & 57,61 & & & & \\
\hline & Slowness in eating & 20-29 Years & 21 & 50,38 & 2 & 1,04 & 0,59 & \\
\hline & & 30-39 Years & 60 & 43,68 & & & & \\
\hline
\end{tabular}




\section{SOCIAL SCIENCES IN THE 21ST CENTURY}

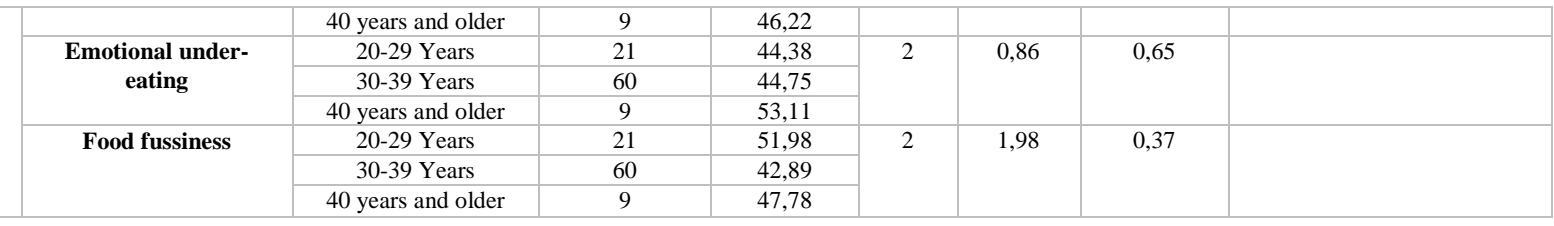

Table 4. Comparison of the differences between the scores of children with ASD in the sub-scales of the BAMBIC and CEBQ by the ages of their mothers

\begin{tabular}{|c|c|c|c|c|c|c|c|c|}
\hline & ANOVA & Variance & Sum Sq. & Mean sq. & sd & $\mathbf{F}$ & $\mathbf{p}$ & Difference \\
\hline \multirow{3}{*}{ 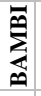 } & \multirow[t]{3}{*}{ Limited variety } & Between groups & 3,45 & 1,73 & 2 & \multirow[t]{3}{*}{0,12} & \multirow[t]{3}{*}{0,89} & \\
\hline & & Within groups & 1304,33 & 14,99 & 87 & & & \\
\hline & & Total & 1307,79 & & 89 & & & \\
\hline \multirow{6}{*}{ 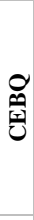 } & \multirow[t]{3}{*}{ Enjoyment of food } & Between groups & 35,30 & 17,65 & 2 & \multirow[t]{3}{*}{0,61} & \multirow[t]{3}{*}{0,55} & \\
\hline & & Within groups & 2533,02 & 29,12 & 87 & & & \\
\hline & & Total & 2568,32 & & 89 & & & \\
\hline & \multirow[t]{3}{*}{ Food fussiness } & Between groups & 7,88 & 3,94 & 2 & \multirow[t]{3}{*}{0,32} & \multirow[t]{3}{*}{0,73} & \\
\hline & & Within groups & 1075,72 & 12,36 & 87 & & & \\
\hline & & Total & 1083,60 & & 89 & & & \\
\hline & Kruskal-Wallis & Group & $\mathbf{N}$ & $\begin{array}{c}\text { Mean } \\
\text { rank }\end{array}$ & sd & $\begin{array}{l}\text { Chi- } \\
\text { sqr. }\end{array}$ & $\mathbf{p}$ & Difference \\
\hline \multirow{6}{*}{ 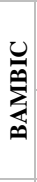 } & \multirow[t]{3}{*}{ Food refusal } & 20-29 Years & 27 & 54,33 & \multirow[t]{3}{*}{2} & \multirow[t]{3}{*}{7,51} & \multirow[t]{3}{*}{$0,02 *$} & \multirow[t]{3}{*}{40 Years and older $>20-29$} \\
\hline & & 30-39 Years & 46 & 45,09 & & & & \\
\hline & & 40 years and older & 17 & 32,59 & & & & \\
\hline & \multirow[t]{3}{*}{ Disruptive behavior } & 20-29 Years & 27 & 50,70 & \multirow[t]{3}{*}{2} & \multirow[t]{3}{*}{7,61} & \multirow[t]{3}{*}{$0,02 *$} & \multirow[t]{3}{*}{$20-29>40$ years and older } \\
\hline & & 30-39 Years & 46 & 46,70 & & & & \\
\hline & & 40 years and older & 17 & 34,00 & & & & \\
\hline \multirow{12}{*}{ 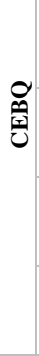 } & \multirow[t]{3}{*}{ Desire to drink } & 20-29 Years & 27 & 52,35 & \multirow[t]{3}{*}{2} & \multirow[t]{3}{*}{2,76} & \multirow[t]{3}{*}{0,25} & \\
\hline & & 30-39 Years & 46 & 43,14 & & & & \\
\hline & & 40 years and older & 17 & 41,00 & & & & \\
\hline & \multirow[t]{3}{*}{ Satiety responsiveness } & 20-29 Years & 27 & 47,44 & \multirow[t]{3}{*}{2} & \multirow[t]{3}{*}{0,69} & 0,71 & \\
\hline & & 30-39 Years & 46 & 46,04 & & & & \\
\hline & & 40 years and older & 17 & 40,94 & & & & \\
\hline & Slowness in eating & 20-29 Years & 27 & 50,35 & 2 & 10,59 & $0,01 *$ & 20-29> 40 years and older \\
\hline & & 30-39 Years & 46 & 49,48 & & & & $30-39>40$ years and older \\
\hline & & 40 years and older & 17 & 27,03 & & & & \\
\hline & Emotional under-eating & 20-29 Years & 27 & 47,98 & 2 & 3,81 & 0,15 & \\
\hline & & 30-39 Years & 46 & 48,14 & & & & \\
\hline & & 40 years and older & 17 & 34,41 & & & & \\
\hline
\end{tabular}

ANOVA and Kruskal-Wallis results revealed that that there was no significant difference between the scores of children with TD in the sub-scales of the BAMBIC and CEBQ by the ages of their fathers ( $p>0.05)$. When the same results were considered for children with ASD, it was found that there was a significant difference between their scores in the food refusal sub-scale by the ages of their fathers $\left(X_{Y R}^{2}(s d=2, n=90)=9,19, \mathrm{p}<0,05\right)$. The nonparametric post hoc test was used to determine the source of this difference. The scores of children with ASD in the food refusal sub-scale were for the fathers aged 20-29 years and 40 years and older, and the fathers aged 30-39 years and 40 years in a way of the disadvantage for those who were aged 40-49 years. According to T-test and Mann Whitney U test, there were no significant differences between the scores of the children with TD in the BAMBIC and CEBQ by the presence of any siblings ( $p>0.05)$.

Table 5. Comparison of the differences between the scores in the sub-scales of the BAMBIC and CEBQ by the presence of any siblings of children with ASD

\begin{tabular}{|c|c|c|c|c|c|c|c|}
\hline & T Test & Group & $\mathbf{N}$ & Mean & sd & $\mathbf{t}$ & $\mathbf{p}$ \\
\hline \multirow[t]{2}{*}{ BAMBIC } & \multirow[t]{2}{*}{ Limited variety } & Yes & 57 & 10,60 & \multirow[t]{2}{*}{88} & \multirow[t]{2}{*}{$-0,70$} & \multirow[t]{2}{*}{0,49} \\
\hline & & No & 33 & 11,18 & & & \\
\hline \multirow{6}{*}{ CEBQ } & \multirow[t]{2}{*}{ Enjoyment of food } & Yes & 57 & 17,88 & \multirow[t]{2}{*}{88} & \multirow[t]{2}{*}{2,96} & \multirow[t]{2}{*}{$0,00^{*}$} \\
\hline & & No & 33 & 14,55 & & & \\
\hline & \multirow[t]{2}{*}{ Satiety responsiveness } & Yes & 57 & 18,42 & \multirow[t]{2}{*}{88} & \multirow[t]{2}{*}{$-1,41$} & \multirow[t]{2}{*}{0,16} \\
\hline & & No & 33 & 20,27 & & & \\
\hline & \multirow[t]{2}{*}{ Slowness in eating } & Yes & 57 & 9,00 & \multirow[t]{2}{*}{88} & \multirow[t]{2}{*}{$-3,35$} & \multirow[t]{2}{*}{$0,00^{*}$} \\
\hline & & No & 33 & 11,55 & & & \\
\hline
\end{tabular}




\begin{tabular}{|c|c|c|c|c|c|c|c|}
\hline & \multirow{2}{*}{ Emotional under-eating } & Yes & 57 & 10,09 & \multirow[t]{2}{*}{88} & \multirow{2}{*}{$-0,80$} & \multirow[t]{2}{*}{0,43} \\
\hline & & No & 33 & 10,73 & & & \\
\hline & Mann Whitney U Test & Group & $\mathbf{N}$ & Mean rank & Sum rank & $\mathbf{U}$ & $\mathbf{p}$ \\
\hline \multirow{4}{*}{ BAMBIC } & \multirow[t]{2}{*}{ Food refusal } & Yes & 57 & 43,45 & 2476,50 & \multirow[t]{2}{*}{823,50} & \multirow[t]{2}{*}{0,32} \\
\hline & & No & 33 & 49,05 & 1618,50 & & \\
\hline & \multirow[t]{2}{*}{ Disruptive behavior } & Yes & 57 & 44,30 & 2525,00 & \multirow[t]{2}{*}{872,00} & \multirow[t]{2}{*}{0,45} \\
\hline & & No & 33 & 47,58 & 1570,00 & & \\
\hline \multirow{8}{*}{ CEBQ } & \multirow{2}{*}{ Food responsiveness } & Yes & 57 & 49,78 & 2837,50 & \multirow[t]{2}{*}{696,50} & \multirow[t]{2}{*}{$0,04 *$} \\
\hline & & No & 33 & 38,11 & 1257,50 & & \\
\hline & \multirow[t]{2}{*}{ Emotional over-eating } & Yes & 57 & 46,89 & 2672,50 & \multirow[t]{2}{*}{861,50} & \multirow[t]{2}{*}{0,50} \\
\hline & & No & 33 & 43,11 & 1422,50 & & \\
\hline & \multirow[t]{2}{*}{ Desire to drink } & Yes & 57 & 48,48 & 2763,50 & \multirow[t]{2}{*}{770,50} & \multirow[t]{2}{*}{0,15} \\
\hline & & No & 33 & 40,35 & 1331,50 & & \\
\hline & \multirow[t]{2}{*}{ Food fussiness } & Yes & 57 & 47,25 & 2693,50 & \multirow[t]{2}{*}{840,50} & \multirow[t]{2}{*}{0,40} \\
\hline & & No & 33 & 42,47 & 1401,50 & & \\
\hline
\end{tabular}

\section{Discussion}

The aim of the study was to examine the eating behaviors of children with TD and ASD by certain variables of their parents. According to the results, it was found that, food refusal is higher in children with ASD while emotional under-eating is higher in children with TD. Such a result imply that emotional under-eating may be an issue that many parents overlook. Parents often stated that emotional under-eating is a more prominent dimension than emotional over-eating (Wardle et al., 2001). Emotional under-eating may occur since reduced intestinal motility due to reduced emotional stability in some cases (Wardle \& Gibson, 2002). Webber, Hill, Saxton, Jaarsveld, and Wardle (2009) reported that emotional under-eating is not associated with children's body mass index. Conversely, it was found that children with emotional over-eating have higher body mass indexes. These two findings led to a conclusion that emotional over-eating and emotional under-eating are not the opposite poles (Webber et al., 2009). The fact that such condition is more prevalent in children with TD than children with ASD is thought to be due to changes in eating behaviors related their emotional status, which is more noticeable by parents whose children with TD. Eating behaviors of children with ASD are known to be different from of their typically developing peers (Provost, 2010; Zimmer et al., 2012; Meral, 2017). In addition, parents whose children with ASD report that their children have more eating problems (Ünal \& Özenoğlu, 2016). Since parents are aware of this, it is thought that it is easier for parents to monitor the periods when their children tend to consume less food. Therefore, it is thought that emotional under-eating is more common in children with TD.

The food refusal sub-scale reveals the refusal behaviors of the child at a mealtime (Hend et al., 2013; Seiverling et al., 2014). Such behaviors are behaviors to avoid eating foods such as keeping its mouth close tightly, food discard, crying, anger etc. (DeMoor et al., 2007). According to the findings, this condition was found to occur more in children with ASD than in children with typical development. As stated in some studies, children with ASD have eating rejection due to food selectivity (Hend et al., 2013; Meral \& Fidan, 2014; Seiverling et al., 2014; Meral, 2017).

It was found that 3-year-old children with ASD have more food refusal and disruptive behaviors than 4-year-old children. In other words, as age advances, refusal and disruptive behaviors decrease. As stated in the study conducted by Seiverling, Hendy, Williams, Fernandez, Alaimo, Galeano, Yamazaki, Yusupova and Hart (2013) by using the BAMBIC, having autism spectrum disorder and being younger are the risk factors for eating behaviors (Seiverling et al. (2013). Similarly, in a study conducted by Hendy, Seiverling, Lukens and Willams (2013), it was determined that younger age group have more food refusal (Hendy et 
al., 2013). In a study conducted by Seiverling, Williams, Adams, Hendy, Alaimo et al. (2016), it was found that younger children get higher scores in the sub-scales of the BAMBIC (food refusal, disruptive behaviors, and limited variety), which can be interpreted as that younger age groups are under more risk on eating behaviors (Seiverling et al., 2016). Similarly, in a study conducted by Berlin, Davies, Silverman, Woods, Fischer and Rudolph (2010) using a scale evaluating eating behaviors, it was observed that younger age groups are more likely to refuse food, avoid eating, and exhibit disruptive behaviors at mealtimes (Berlin et al., 2010). The fact that the sample group selected in the current study attend special education and rehabilitation centers and receive nutritional trainings in these centers may reduce the problems in eating behaviors as they grow older.

According to the results pertaining to the differences between the scores of children with ASD and TD in the BAMBIC and CEBQ by the ages of their mothers and fathers, the food refusal behaviors are higher in children with TD whose mothers are 20-29 years while such behaviors are higher in children with ASD whose mothers and fathers are 40 years and older compared to the ones whose parents are 20-29 years. In other words, ages of mothers of children with TD and ASD appears to be opposite to each other. This situation is thought to be caused by the developmental differences of children with ASD and TD and responsibility of their parents in terms of their self-care skills. In a study conducted by Ünlü (2011), it was found that the children whose fathers are 30 years and younger exhibited more negative behaviors during mealtimes than the ones whose fathers are older (Ünlü, 2011).

It was determined that eating behaviors of typically developing children do not differ by their fathers' ages. In Turkish culture, it is known that mothers take more responsibility for the care of the child while fathers are more in second place compared to mothers (Demiriz \& Dinçer, 2000). Therefore, it is an expected result that mothers may play a more important role on eating behaviors of children with TD. In the study conducted by Metbulut (2016), it was determined that the engagement of fathers on child nutrition is 15\% (Metbulut, 2016). As can be seen from the results, fathers play a less effective role in feeding the child. However, this is not only related to the paternal age for children with TD but also it is thought that paternal age shows significant difference with the eating behaviors of children with ASD and that their parents have more responsibility in developmental processes of children with ASD (Provost et al., 2010, Selimoğlu et al., 2013). It is also believed that fathers have a critical role in the nutrition of children (Atzaba-Poria, 2010).

The scores of children with ASD in the sub-scale disruptive behaviors revealed a significant difference with maternal age. Children with ASD whose mothers are 20-29 years showed more disruptive behaviors than the ones whose mothers are 40 years and older. In other words, it was determined that the children of mothers with younger age tend to exhibit more disruptive behaviors during mealtimes. According to a study conducted by Bekiroğlu, Akbaş and Taşdemir (2009), parental age was found to be related to the level of psychiatric problems in children (Karabekiroğlu et al., 2009). Moreover, according to Erikson's Psychosocial Development Theory, the ages of 20-30 are called young adulthood and the conflict of this period is expressed as "intimacy versus isolation". In this period, it is observed that individuals have goals such as establishing social relations, maintaining these relations, establishing business and family, and gaining status (Bayhan \& Artan, 2012; Santrock, 2012). It is considered that parents who are in such conflicts will have less time to devote to their children's eating problems than parents aged 40 years and older and therefore, more disruptive behaviors are likely to be seen in their children during mealtimes. On the other hand, children of mothers aged 20-29 years and 30-39 years are more likely to show slow eating behaviors 


\section{SOCIAL SCIENCES IN THE 21ST CENTURY}

when compared the ones of mothers aged 40 years and older. According to Erikson's Psychosocial Development Theory, the 40s are called middle adulthood. The conflict of this period is expressed as "generativity versus stagnation". The individual in this period continues to produce and aims to use its productivity as a guide for increasing the efficiency of next generation (Bayhan \& Artan, 2012; Santrock, 2012). It is assumed that parents in this age group will have efforts to find solutions in a way of conveying more experiences on their children's eating behaviors. Therefore, it is believed that children of mothers aged 20-29 years and 30-39 years may exhibit slow eating behaviors when compared to the ones of those aged 40 years and older.

While presence of any siblings generates no differences in children with TD, children with ASD are more likely to show enjoyment of food and food responsiveness behaviors if they have a sibling. While $52 \%$ of the children with TD have siblings, this ratio is $63 \%$ in children with ASD. Considering the characteristics of the sample group, it is thought that the sample size is likely to influence the results since the number of children with ASD having a sibling is higher than the other group. Sibling is the one who becomes a model for a child with its positive and negative behaviors (Aksoy, 2016). The fact that children with ASD having siblings show more enjoyment of food and food responsiveness behaviors raise the issue that children learn by taking their siblings as models and are more interested in eating by interacting with their siblings because family members, siblings and peers can be models for children to taste new foods (Öztürk, 2010). Children reflect such model behaviors on their own eating behaviors. According to a study, it was found that children with siblings having special needs take responsibility physically and cognitively to overcome stressful conditions of their siblings (Cox et al., 2003). It is believed that responsibilities undertaken by the children for their siblings with special needs may have positive effects on such siblings' eating behaviors and will positively affect their enjoyment of food and food responsiveness.

\section{Acknowledgment}

This paper was prepared by the authors as a dissertation thesis in Hacettepe University Institute of Health Sciences. The author(s) received no financial support for the research.

\section{References}

[1] Aksoy, P. (2016). Aile içi ilişkiler ve iletişim (Family relations and communication). Baran, G. (Ed.) Aile Yaşam Dinamiği (Family Life Dynamics), 67-103.

[2] Atzaba-Poria, N., Meiri, G., Millikovsky, M., Barkai, A., Dunaevsky-Idan, M., \& Yerushalmi, B. (2010). Father-child and mother-child interaction in families with a child feeding disorder: The role of paternal involvement. Infant Mental Health Journal, 31(6), 682-698.

[3] Balikçi, Ö. S., \& Çiyiltepe, M. (2017). Feeding problems of children with autism. People: International Journal of Social Sciences, 3(1).

[4] Bayhan, P. \& Artan, İ. (2012). Çocuk gelişimi ve eğitimi (Child development and education). Istanbul: Morpa Publishing.

[5] Baysal, A. \& Arslan, P. (2007). Doğumdan yetişkinliğe çocuk yemekleri çocuğun bilinçli ve sağlıklı beslenmesi. (Child meals from birth to adulthood: conscious and healthy nutrition of the child) Istanbul: Ozgür Publising. 


\section{SOCIAL SCIENCES IN THE 21ST CENTURY}

[6] Bee, H. and Boyd, D. (2009). Çocuk gelişim psikolojisi (Child development psychology). Istanbul: Kaknus publishing.

[7] Berk, L. E. (2015). Infants and children. Erdoğan, N. I. (Ed.) Ankara: Nobel Publising.

[8] Berlin, K. S., Davies, W. H., Silverman, A. H., Woods, D. W., Fischer, E. A. and Rudolph, C. D. (2010). Assessing children's mealtime problems with the Mealtime Behavior Questionnaire. Children's Health Care, 39(2), 142-156.

[9]Bilbay, A. (2015). Özel gereksinimli bebekler ve çocuklarda duyu gelişimi. (Sensory development in infants and children with special needs) Bıçakçı, M.Y. (Ed.) Ankara: Egiten Books.

[10]Brown, T. Confirmatory factor analysis for applied research. Guilford: New York ve London; 2015.

[11] Cox, A. H., Marshall, E. S., Mandleco, B., and Olsen, S. F. (2003). Coping responses to daily life stressors of children who have a sibling with a disability. Journal of Family Nursing, 9(4), 397-413.

[12] Demiriz, S. and Dinçer, Ç. (2000). Okulöncesi dönem çocuklarının öz bakım becerilerinin annelerinin çalışıp çalışmama durumlarına göre incelenmesi. (A study on preschool children's self-help skills according to their mother's working status) Hacettepe Üniversitesi Eğitim Fakültesi Dergisi, 19(19).

[13] De Moor, J., Didden, R. and Korzilius, H. P. L. M. (2007). Behavioural treatment of severe food refusal in five toddlers with developmental disabilities. Child: care, health and development, 33(6), 670-676.

[14] Erdoğan, S., Nahcivan, N. and Esin, M. N. (2014). Hemşirelikte araştırma süreç, uygulama ve kriter (Research process, application and criteria in nursing). Istanbul: Nobel Tip Kitapevleri.

[15] Karabekiroğlu, K., Akbaş, S. and Taşdemir, G. N. (2009). Anne Sütü Alma Süresi Erken Çocukluk Dönemi Psikiyatrik Sorunları İçin Özgül Bir Risk Faktörü Müdür? (Is the Duration of Breast Feeding A Specific Risk Factor on Psychiatric Complaints in Toddlerhood?). Türkiye Çocuk Hastalıkları Dergisi, 3(3), 24-33.

[16] Karasar, N. (2009). Bilimsel Araştırma Yöntemi (Scientific Research Methods). Ankara: Nobel Publishing.

[17] Kaya, M. (1999). Ana-baba eğitimi desteklı beslenme eğitiminin 3-6 yaş grubu çocukların beslenme bilgisi ve davranışlarına etkisi. (Comparison of Mother and Child Health and Nutrition Habits of the Nursery School Kids in Preschool Period (Aged 3-6)) Ankara: Gazi University.

[18] Köksal, G. and Gökmen, H. (2016). Çocuk Hastalıklarında Beslenme Tedavisi (Nutritional Treatment in Pediatric Diseases). Ankara: Hatiboğlu publishing.

[19] Hendy, H. M., Seiverling, L., Lukens, C. T. and Williams, K. E. (2013). Brief assessment of mealtime behavior in children: Psychometrics and association with child characteristics and parent responses. Children's Health Care, 42(1), 1-14.

[20] Hendy, H., Harclerode, W. and Williams, K. E. (2016). The Parent Mealtime Action Scale revised (PMAS-R): Psychometric characteristics and associations with variables of clinical interest. Appetite, 105, 283-290. 


\section{SOCIAL SCIENCES IN THE 21ST CENTURY}

[21] MEB. (2013a). 0-36 aylık çocuklar için eğitim program (Educational program for children aged 0-36 months). In: https://tegm.meb.gov.tr/dosya/okuloncesi/036ayliksaglikbakimeslenme.pdf, Ankara: Ministry of National Education General Directorate of Basic Education.

[22] Meral, B. F. and Fidan, A. (2014). Psychometric properties of the screening tool of feeding problems (STEP) in Turkish children with ASD. Research in developmental disabilities, 35(4), 908-916.

[23] Meral, B. F. and Fidan, A. (2015). Measuring the impact of feeding covariates on health-related quality of life in children with autism spectrum disorder. Research in Autism Spectrum Disorders, 10, 124-130.

[24] Meral, B. F. (2017). Otizm spektrum bozukluğu olan çocuklarda beslenme problemleri ve bilimsel dayanaklı davranısssal müdahaleler (Nutrition Problems in Children with Autism Spectrum Disorder and Science-based Behavioral Interventions). Ankara University Faculty of Educational Sciences Journal of Special Education, 18(03), 493508.

[25] Metbulut, A. P. (2016). Sağlikli 2-5 yaş arasindaki çocuklarda anne ve büyükanne besleme tutumlari ve çocuklarda beslenme sorunlarinin değerlendirilmesi (Mother and grandmother's feeding attitudes towards healthy children aged 2-5 years and an evaluation of nutritional problems in children) (Dissertation). Ankara: Hacettepe University.

[26] Öz, N. S. (2019). Tipik Gelişen ve Otizm Spektrum Bozukluğu Olan Çocukların Yeme Davranışları ve Ebeveynlerin Yemek Zamanı Tutumları Arasındaki İlişkinin İncelenmesi. (Analysing of The Relation Between The Eating Habit of The Children Who Has Autism Spectrum Disorder And Children With Typical Development and The Eating Habit of These Children Parents Also Their Behavior to Their Children While Eating Time) (Master's Thesis). Ankara: Hacettepe University.

[27] Öztürk, M. (2010). Çocukların beslenme alışkanlıklarının sağlık davranışı etkileşim modeline göre İncelenmesi. (Evaluation of Children"s Dietary Habits According to the Interaction Model of Client Health Behavior. Istanbul University, Institute of Health Science, Department of Public Health Nursing) Istanbul: Istanbul University School of Health Sciences.

[28] Provost, B., Crowe, T. K., Osbourn, P. L., McClain, C. and Skipper, B. J. (2010). Mealtime behaviors of preschool children: Comparison of children with autism spectrum disorder and children with typical development. Physical \& Occupational Therapy in Pediatrics, 30(3), 220-233.

[29] Santrock, J. W. (2012). Life-span development. Ankara: Nobel.

[30] Seiverling, L. J., Williams, K. E., Hendy, H. M., Adams, K., Fernandez, A., Alaimo, C. and Hart, S. (2016). Validation of the Brief Assessment of Mealtime Behavior in Children (BAMBIC) for children in a non-clinical sample. Children's Health Care, 45(2), 165-176.

[31] Selimoğlu, Ö. G., Özdemir, S., Töret, G. and Özkubat, U. (2013). Otizmli çocuğa sahip ebeveynlerin otizm tanılama sürecinde ve tanı sonrasında yaşadıkları deneyimlerine ilişkin görüşlerinin incelenmesi. (An Examination of the Views of Parents of Children With Autism About Their Experiences at the Post-Diagnosis Period of Autism) International Journal of Early Childhood Special Education, 5(2), 129-161. 


\section{SOCIAL SCIENCES IN THE 21ST CENTURY}

[32] Sharp, W. G., Burrell, T. L. and Jaquess, D. L. (2014). The Autism MEAL Plan: A parent-training curriculum to manage eating aversions and low intake among children with autism. Autism, 18(6), 712-722.

[33] Sümbül, İ. E. (2009). 4-6 Yaş Arasındaki Öğrencilerin Okul Dönemindeki Yetersiz ve Dengesiz Beslenme Alışkanlıklarının Saptanması. (Determination of The Insufficient and Unbalanced Eating Behaviors of 4-6 Years Old School Term Children) Konya: Selcuk University.

[34] Uçar, K. and Samur, G. (2017). Otizmin Tedavisinde Güncel Yaklaşımları (Contemporary Approaches to Autism Treatment). Journal of Nutrition and Dietetics. 45(1): 53-60.

[35] Uyaroğlu, B. (2016). Özbakım becerilerinin gelişimi (Development of self-care skills). Metin, E. N., (Ed.) Ankara: Pegem Academy.

[36] Ünlü, H. (2011). Okul öncesi dönem çocuklar için yeme davranışı değerlendirme ölçeğinin Türk çocuklarına uyarlanması (Adapting the children's eating behavior inventory in preschool period for Turkish children) (Master's Thesis). Istanbul: Marmara University.

[37] Wardle, J., Guthrie, C. A., Sanderson, S. and Rapoport, L. (2001). Development of the children's eating behaviour questionnaire. The Journal of Child Psychology and Psychiatry and Allied Disciplines, 42(7), 963-970.

[38] Wardle, J. and Gibson, E. L. (2002). Impact of stress on diet: processes and implications. BMJ Books.

[39] Webber, L., Hill, C., Saxton, J., Van Jaarsveld, C. H. M. and Wardle, J. (2009). Eating behaviour and weight in children. International journal of obesity, 33(1), 21

[40] Yavuzer H. (2013). Bedensel, zihinsel ve sosyal gelişimiyle çocuğunuzun ilk 6 yılı (Your child's first 6 years with physical, mental and social development). Istanbul: Remzi Publishing.

[41] Yavuzer, H. (2016). Mother-father and child. Istanbul: Remzi Publishing.

[42] Yılmaz, R., Esmeray, H. and Erkorkmaz, Ü. (2011). Çocuklarda yeme davranış1 anketinin Türkçe uyarlama çalışması. (Adaptation study of the Turkish children's eating behavior questionnaire) Journal of Anatolian Psychiatry.12:287-94.

[43] Zimmer, M. H., Hart, L. C., Manning-Courtney, P., Murray, D. S., Bing, N. M. and Summer, S. (2012). Food variety as a predictor of nutritional status among children with autism. Journal of autism and developmental disorders, 42(4), 549-556. 